\title{
BODY POSITION AND THE FUNCTIONAL MORPHOLOGY OF CRETACEOUS HETEROMORPH AMMONITES
}

\author{
Neale Monks and Jeremy R. Young
}

\begin{abstract}
Previous analyses of ammonite functional morphology have assumed that the animal filled the entire body chamber, and that movement of the animal (such as withdrawal of the head and arms into the shell) had little effect on orientation. An alternative anatomy is proposed here: the ammonite animal was small, mobile, and capable of moving away from the aperture when threatened. The effect of this anatomy on the hydrostatics of aspinoconic, ancycloconic, and hamiticonic heteromorph ammonites is analysed. This analysis suggests that movement of the body would significantly alter the distribution of mass and hence orientation.
\end{abstract}

Neale Monks and Jeremy R. Young, Department of Palaeontology, Natural History Museum, Cromwell Road, South Kensington, London, SW7 5BD, UK.

Key Words: ammonite, functional morphology, body chamber, anatomy, aperture, hydrostatics, aspinoconic, ancycloconic, hamiticonic, heteromorph, Ancycloceratida, Lower Cretaceous

\section{INTRODUCTION}

Interpretations of the functional morphology of fossil cephalopods have tended to concentrate on those that resemble extant cephalopods (e.g., belemnites compared to squid, Monks et al. 1996; regularly coiled ammonites to Nautilus, Chamberlain 1976, 1980). Fossil cephalopods that do not have such clear analogues, such as the Lower Cretaceous heteromorph ammonites, are more problematical. Moreover, it is unclear how far Nautilus is a valid analogue for ammonites.

Nautilus has paired retractor muscles that can pull the head and arms into the shell when the animal is threatened. The aperture is also sealed by a tough hood, functionally similar to the gastropod operculum (Wells et al. 1992). However, the Nautilus body chamber is short, approximately one third of a whorl in length, and the animal cannot withdraw far. In contrast, the living chambers of ammonites are very long and often narrow. Moreover, ammonites lacked a hood or operculum. [Note: the aptychi are now generally accepted to have been part of the jaws (Lehmann 1981)]. Consequently, the assumption that the soft parts of the ammonite filled the entire living chamber of the shell is not neccessarily correct, and it is possible that without a way of sealing the aperture, ammonites may have been capable of withdrawing further into the shell than has heretofore been acknowledged. 
Body position in heteromorph ammonites is important because the association of the soft body (e.g., head, arms, viscera) with the shell is a key part of understanding how these animals lived and functioned. The discussion by Trueman (1941) on this topic is widely quoted (e.g., in the Treatise on Invertebrate Paleontology, Arkell et al. 1957). Trueman assumed that the entire living chamber was filled, and used this to deduce the centres of mass and buoyancy of the ammonite. Ammonite functional interpretations based on this model are characterised by a single stable orientation, with the centre of mass vertically below the centre of

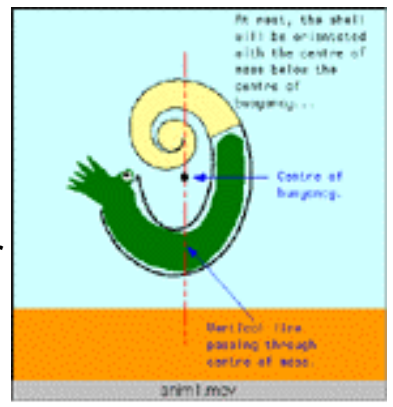

Animation 1. buoyancy. For heteromorph ammonites this model typically predicts upturned apertures (Anim. 1). Many workers have cited these upturned apertures as evidence that heteromorphs were pelagic plankton feeders (e.g., Klinger 1980, Westermann 1996).

More recently, Kakabadzé and Sharikadzé (1993) proposed that the heteromorph shell had two stable orientations, one with the aperture pointing upwards (as in previous interpretations) and a second with the aperture tilted towards the sea floor. This alternative orientation would make it possible for heteromorph ammonites to feed off the sea floor. Kakabadzé and Sharikadzé (1993) also proposed that these ammonites might have been able to adjust their bouyancy by shifting cameral fluid within the shell. This would change the position of the centre of mass, and consequently the orientation of the shell (Anim. 2).

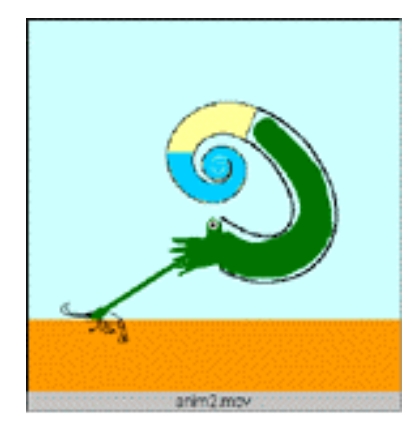

Animation 2.

The idea that ammonites may have had more than one stable orientation has not been widely discussed by ammonite workers, but if true could force a re-appraisal of ammonite paleoecology. The Kakabadzé and Sharikadzé (1993) model relies on ammonites being able to rapidly change the distribution or amount of fluid within the shell. As far as is known, movement of fluid within the shell of ectocochleates is slow. In Nautilus, changes in the amount of fluid within the chambers is too slow even to assist diurnal migration by adjusting overall buoyancy (Chamberlain 1991).

Cuttlefish have a highly modified and characteristic shell, divided into numerous small chambers, subdivided by conchiolin walls, and exhibiting a broad siphuncular region rather than a narrow siphuncle (Denton \& Gilpin-Brown 1961a). This appears to allow the cuttlefish to make changes to the buoyancy of the shell more quickly than Nautilus (Denton \& Gilpin-Brown 1961b). Even so, buoyancy regulation in cuttlefish seems not to be used as the primary device for rising or sinking in the water column, but rather for acquiring neutral buoyancy once a preferred depth has been reached (Denton 1973). Ammonite shells are quite unlike the shells

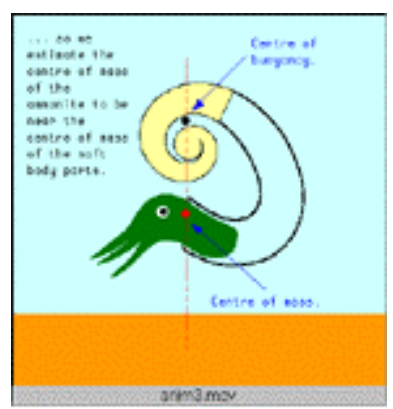

Animation 3. of cuttlefish and so it is more likely that Nautilus is an appropriate analogue in this respect. As a result, the problem remains that while changes in 
orientation may have been possible, no entirely convincing mechanism has been proposed for how this might have been acomplished. We propose a third possible anatomy: That the heteromorph ammonite animal was a relatively small, mobile creature that was able to move within its floating shell rather like a modern gastropod. As with the previous model this allows significant changes in orientation, due in this case to changes in the distribution of the mass as the body moves within the shell (Anim. 3).

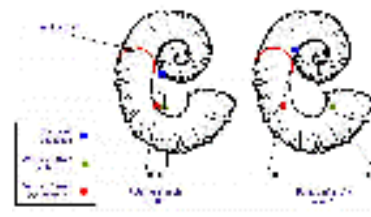

Figure 1.

The only direct evidence for soft part

morphology in ammonites is provided by the muscle scars. These are consistently located near the rear of the living chamber, close to the final septum (Crick 1898). Such a muscular arragement is compatible with our model of a

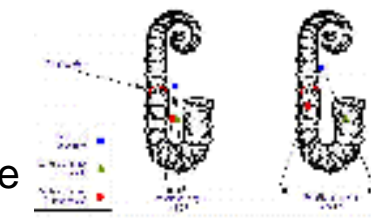

Figure 2. small retractable body although clearly it does not prove it. Heteromorph ammonite shells are characterized by a departure from the regular planispiral shape of most other ammonites. One of the most common themes in heteromorph shell design is that of the planispiral phragmocone and hook-shaped living chamber.

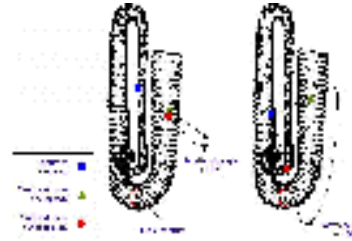

Figure 3.

The simplest form is that of the aspinocone, where the living chamber consists of a shallow U-shaped hook held slightly away from the planispiral phragmocone (Fig. 1). By drawing the hook deeper into two parallel shafts, the ancyclocone is produced (Fig. 2). Finally, straightening all but the earliest stages of the phragmocone and tightening the bends further results in the hamiticone (Fig. 3).

\begin{abstract}
ANALYSIS
The orientation of a submerged body is determined by the positions of its centre of buoyancy and centre of mass. The centre of buoyancy is effectively the pivot point about which the shell rotates. Since the centre of mass will, at rest, lie directly below this point, deducing its location is critical to identifying shell orientation. To demonstrate the effect of moving a small, heavy body within a freely floating shell it is thus necessary to locate the centre of buoyancy and the centre of mass.
\end{abstract}

The centre of buoyancy is the centre of gravity of the displaced fluid in which the body is immersed. In the models proposed by Trueman (1941) and Kakabadzé \& Sharikadzé (1983), the water displaced is approximately equal to the volume of the phragmocone and the living chamber, since both are filled (the phragmocone with gas and cameral 
fluids, the living chamber with the animal). In contrast, our model reduces the size of the animal such that most of the living chamber is empty. Thus most of the water is displaced by the phragmocone.

The centre of mass is the point at which, from a gravitational point of view, the total mass may be considered to be concentrated. For Trueman, the heaviest part of the ammonite was the body, which filled most of the living chamber. Kakabadzé \& Sharikadzé also considered the fluids within the phragmocone. We have concentrated the mass of the animal in a smaller volume.

The centre of buoyancy were found by producing a Plasticene model of that part of the ammonite which displaces water and identifying its centre of mass. Since the density of the Plasticene is uniform, its centre of mass will lie at the same point as a similarlyshaped mass of water. The Plasticene models were suspended from an arbitrary point by a light thread and allowed to come to rest. A vertical line was drawn from the point of suspension downwards. This was repeated for a number of different suspension points. The lines cross at the centre of mass of the Plasticene shape. In this way the centre of buoyancy of the ammonite can be estimated.

The centre of mass is more difficult to deduce since we know nothing about the density or mass distribution of the ammonite soft body parts or how much fluid was within the shell. We follow Trueman's assumption that it lay close to the centre of mass of the body, the most massive part of the animal, which is taken to be of uniform density.

\section{RESULTS}

Three different shapes of heteromorph ammonites were examined: an aspinocone, Tropaeum; an ancyclocone, Ancycloceras; and an hamiticone, Hamites. The centres of mass and buoyancy are plotted on diagrams of these shells under the models proposed by Trueman (Figs 1a, 2a, 3a) and in this paper (1b, 2b, 3b).

The rotational angle measured is the maximum that could be developed when the ammonite body moved between the aperture and the final septum. The greatest change in orientation (i.e., the greatest rotational angle) would potentially occur in the hamiticone ammonite, which has a long and straight body chamber. The rotational angles are listed in Table 1.

\section{DISCUSSION}

It is generally accepted that heteromorph ammonites were poor swimmers, on the basis of overall shape and position of the aperture, although the dispersive juvenile stages and some adult forms may have been quite mobile planktonic drifters (Ward 1986, 1979, Shigeta 1993, Westermann 1996). Klinger (1980) demonstrated that helically coiled and orthocone ammonites must have been oriented in life with the head downwards, and suggested that these animals may have foraged on the sea floor, perhaps jetting vertically upwards when disturbed. Ebel (1992) reconstructed a number of heteromorph ammonites (such as Scaphites and Nipponites) with large bodies unable to retract into the shell, and that overall they were negatively buoyant (the float 
being too small in proportion to the body). Instead, Ebel (1992) proposed that these animals crawled along the sea floor on muscular arms like modern Octopus.

Our model contrasts with Ebel (1992) in proposing that instead of the body being much larger than analogy with Nautilus would suggest, it was much smaller, and more like a gastropod. However, like Ebel (1992) and Klinger (1980) we believe many heteromorph ammonites were nektobenthonic. In support of this interpretation there is good evidence that at least some ammonites lived on the sea floor. Gut contents reveal that some ammonites fed on benthic foramanifera, ostracods, crinoids, crustaceans and other ammonites, perhaps also scavenging (Lehmann 1973, Lebrun 1996). The absence of a hyponomic sinus in most ammonites (and all heteromorphs) suggests the hyponome was weakly developed, if present at all, and the sort of manoeuvrable jetting seen in Nautilus is unlikely. Indeed Géczy (1960) has argued that ammonites probably lacked the ability to swim. That Jurassic and Cretaceous heteromorph ammonites are usually found in clay or marl rather than sandy facies also suggests that the heteromorph ammonites were substrate dependent (Marcinowski \& Wiedmann 1990). There are examples of ammonite specimens that seem to have been preserved as part of the benthos (e.g., a school of Polyptychoceras, a hamiticonic form) "nesting" within the shell of an Eupachydiscus (Matsumoto \& Nihongo 1979). Finally, periodic disappearance of some heteromorphs during times of bottom water anoxia has been noted (e.g., Scaphites and Hamites from the Western Interior sea, Batt 1989). In addition it may be noted that the Hamitidae are essentially confined to shelf sediments (Westermann 1996).

With a small, mobile body within the long body chamber, a heteromorph ammonite can be visualised as having been rather like a small octopus with a mobile burrow or cave. When feeding, the aperture would have been angled toward the sediment allowing the animal to forage the sediment, perhaps pulling itself along with its arms, digging up small molluscs, worms and crustaceans. When alarmed, the ammonite would have withdrawn deep into the shell, and waited for the danger to pass. Because of the change in position of the centre of mass, the shell would have rotated away from the substrate. Rather than swimming away, the ammonite may have relied on the mechanical defences of spines (making the shell difficult to crush) and ribs (to hinder peeling). The long body chamber of the ammonite would also have served to make the animal difficult to pull out. Similar adaptations are well documented in gastropods (Vermeij 1993). This mode of life is similar to that suggested by Kakabadzé and Sharikadzé (1993), but since the orientation of the shell relative to the substrate becomes a function of the position of the animal within the shell and the geometry of the shell itself; the requirement for movement of cameral fluids around the shell is eliminated.

Other interpretations of heteromorph ammonite morphology include partial emergence of the mantle cavity from the shell (Jacobs and Landmann 1993); investment of the shell within mantle tissues (Doguzhaeva and Mutvei 1993); and even a free living ammonite animal using the shell as an egg case (Lewy 1996). However, for all these interpretations the evidence is circumstantial at best. Our model has the advantage of requiring less divergence from modern cephalopods in terms of behaviour or anatomy, 
being in accord with the more conservative views on ammonite ecology, and suggesting the possibility of lifestyles hitherto unconsidered.

\section{CONCLUSION}

The orientation of heteromorph ammonites depends upon on the positioning of the soft body parts of the animal within the shell. We propose that the body was a relatively small, compact mass only partially filling the living chamber. As the body moved from the aperture to the final septum and then back again, the centre of mass would be predicted to move in such a way as to cause the shell to rotate. The magnitude of this change is a function of shell shape, especially of coiling pattern. This effect may provide a functional explanation of heteromorph shell geometry. In addition, wider application of the model may lead to reinterpretations of the life modes of other ammonite groups.

\section{ACKNOWLEDGMENTS}

Thanks are due to the Natural History Museum for financing this work as part of an internal graduate studentship. J. D. Hardwick (Imperial College) was especially helpful with some of the technical aspects. We also thank two anonymous referees for their useful comments, and N. MacLeod for his editorial assistance.

\section{REFERENCES}

Arkell, W. J., Kummel, B., \& Wright C. W. 1957. Mesozoic Ammonoidea, p. L80-L490. In Moore, R. C. (ed.), Treatise on Invertebrate Paleontology, Part L, Mollusca 4. Geological Society of America \& University of Kansans Press, Lawrence, Boulder, Colorado \& Lawrence, Kansas.

Batt R. J. 1989. Ammonite shell morphotype distributions in the Western Interior Greenhorn Sea and some paleoecological implications. Palaios, 4: 32-42.

Chamberlain J. A. 1976. Flow patterns and drag coefficients of cephalopod shells. Palaeontology, 19: 539-563.

Chamberlain J. A. 1980. Motor performance and jet propulsion in Nautilus: implications for cephalopod paleobiology and evolution. Bulletin of the American Malacological Union, 123-127.

Chamberlain J. A. 1991. Cephalopod locomotor design and evolution. the constraints of jet propulsion, p. 57-98. Biomechanics in Evolution, Society for Experimental Biology Seminar Series 36. Cambridge University Press, Cambridge, UK.

Crick G. C. 1898. On the muscular attachment of the animal to its shell in some Fossil Cephalopoda (Ammonoidea). Transactions of the Linnaean Society of London (Zoology), 7: 71-113.

Denton E. J. 1973. On buoyancy in the lives of modern and fossil cephalopods. Proceedings of the Royal Society of London Series B, 185: 273-299.

Denton E. J. \& Gilpin-Brown J. B. 1961b. The buoyancy of the cuttlefish Sepia. Journal of the Marine Biological Association of the United Kingdom, 41: 319-342.

Denton E. J. \& Gilpin-Brown J. B. 1961c. The effect of light on the buoyancy of the cuttlefish. Journal of the Marine Biological Association of the United Kingdom, 41: 343-350.

Denton E. J. \& Gilpin-Brown J. B. 1961a. The distribution of gas and liquid within the cuttlebone. Journal of the Marine Biological Association of the United Kingdom, 41: 365-381. 
Doguzhaeva L. and Mutvei H.1993. Structural features in Cretaceous ammonids indicative of semiinternal or internal shells, p. 99-114. In House, M. R. and Senior, J. R. (eds.), The Ammonoidea. Systematics Association Special Volume 47. Clarendon Press, Oxford, UK.

Ebel K. 1992. Mode of life and soft body shape of heteromorph ammonites. Lethaia, 25: 179-193.

Geczy B. 1960. A Neoammoideak eletmodjarol . Foldtani Kozlony Magyar Foldtani Tarsulat, 90: 200203.

Jacobs D. K. and Landman N. H. 1993. Nautilus-A poor model for function and behaviour of ammonoids? Lethaia, 26: 101-188.

Kakabadzé M. V, and Sharikadzé M. Z. 1993. On the mode of life of heteromorph ammonites heterocone, ancyclocone, ptychocone), p. 209-215. In S. Elmi, C. Mangold and Y. Almeras (eds.), 3-eme Symposium international sur le Cephalopodes actuels et fossiles. Geobios Memoire Special 15.

Klinger, H. C. 1980. Speculations on Buoyancy Control and Ecology in some Heteromorph Ammonites, p. 337-355. In House, M. R. and Senior, J. R. (eds.), The Ammonoidea. Systematics Association Special Volume 18. Academic Press, London, UK.

Lebrun P. 1996. Ammonites. Minéraux et Fossiles, Hors-Série 4: 1-96.

Lehmann U. \& Weitschat W, 1973. Zur Anatomie und Okologie von Ammoniten: Funde von Kropf und Kiemen. Paläontologische Zeitschrift, 47: 69-76.

Lehmann U. 1981. The Ammonites. 246 pp. Cambridge University Press, Cambridge, UK.

Lewy Z. 1996. Octopods: Nude ammonoids that survived the Cretaceous-Tertiary boundary mass extinction. Geology, 24: 627-630.

Marcinowski R. \& Wiedmann J. 1990. The Albian ammonites of Poland. Palaeontologica Polonica, 50: $1-94$

Matsumoto T. \& Nihongi M. 1979. An interesting mode of occurrence of Polyptychoceras (Cretaceous Heteromorph Ammonoid). Proceedings of the Japan Academy Series B, 55: 115-119.

Monks N., Hardwick J. D., and Gale A. S. 1996. The function of the belemnite guard. Paläontologische Zeitschrift, 70: 425-431.

Shigeta Y. 1993. Post-hatching and early life history of Cretaceous ammonoidea. Lethaia, 26: 133-145.

Trueman A. E. 1941. The ammonite body-chamber, with special reference to the buoyancy and mode of life of the living ammonite. Quarterly Journal of the Geological Society of London, 384: 339-383.

Vermeij G. J. 1993. A Natural History of Shells. Princeton University Press, New Jersey, USA. vii +207 pp, 22 pls.

Ward P. D. 1979. Functional morphology of Cretaceous helically-coiled ammonite shells. Paleobiology, 5: 415-422.

Ward P. D. 1986. Cretaceous ammonite shell shapes. Malacologia, 27: 3-28.

Ward P. D., Stone R., Westermann G. E. G. and Martin, A. 1977. Notes on animal weight, cameral fluids, swimming speed and colour polymorphism of the cephalopod Nautilus macromphalus in the Fiji Islands.

Paleobiology, 3: 377-388.

Wells M. J. 1987. Ventilation and oxygen extraction by Nautilus, p. 339-350. In W. B. Saunders and N. H. Landman (eds.), Nautilus: The Biology and Palaeobiology of A Living Fossil. Plenum Press, New 
York, USA.

Wells M. J. and Wells J. 1985. Ventilation and oxygen uptake by Nautilus. Journal of Experimental Biology, 118: 297-312.

Wells M. J., Wells J., and O'Dor R. K. 1992. Life at low oxygen tensions: the behaviour of Nautilus pompilius and the biology of extinct forms. Journal of the Marine Biological Association of the United Kingdom, 72: 313-328.

Westermann G. E. G. 1996. Ammonoid life and habit, 607-707. In Landman N. H., Tanabe K., Davis R. A. (eds.), Ammonoid Paleobiology, Topics in Geobiology Volume 13. Plenum Press, New York, USA. 
Figure 1. Centres of buoyancy (blue squares) and mass (green triangle and red circle) for Tropaeum hillsi deduced using Trueman's model with the body chamber entirely filled (left); and the model presented herein, with the body chamber only partially filled (right). The green triangle indicates the position of the centre of mass when the head and arms are extended; the red circles when withdrawn.

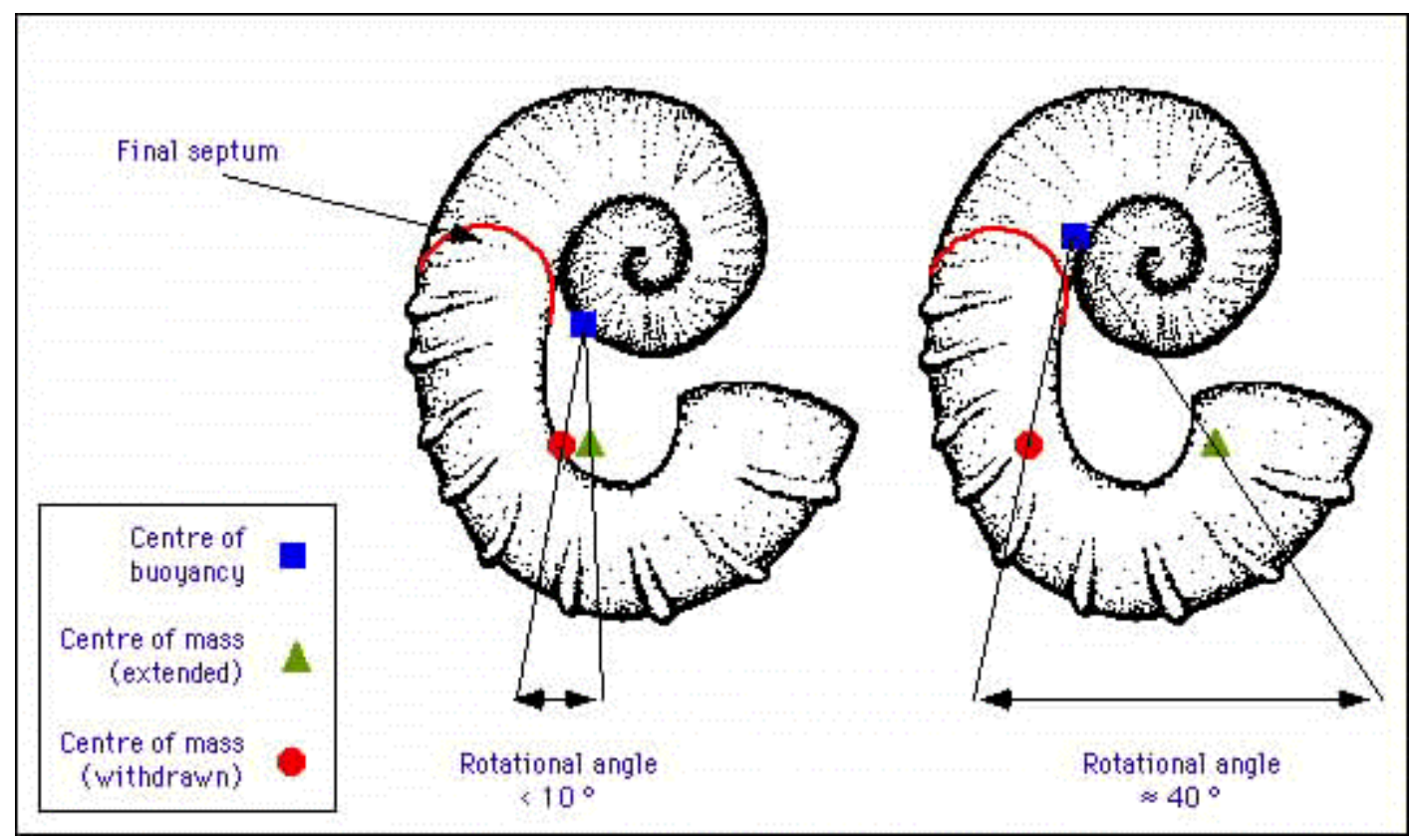


Figure 2. Centres of buoyancy (blue squares) and mass (green triangle and red circle) for Ancycloceras matheronianum deduced using Trueman's model with the body chamber entirely filled (left); and the model presented here, with the body chamber only partially filled (right). The green triangle indicates the position of the centre of mass when the head and arms are extended; the red circles when withdrawn.

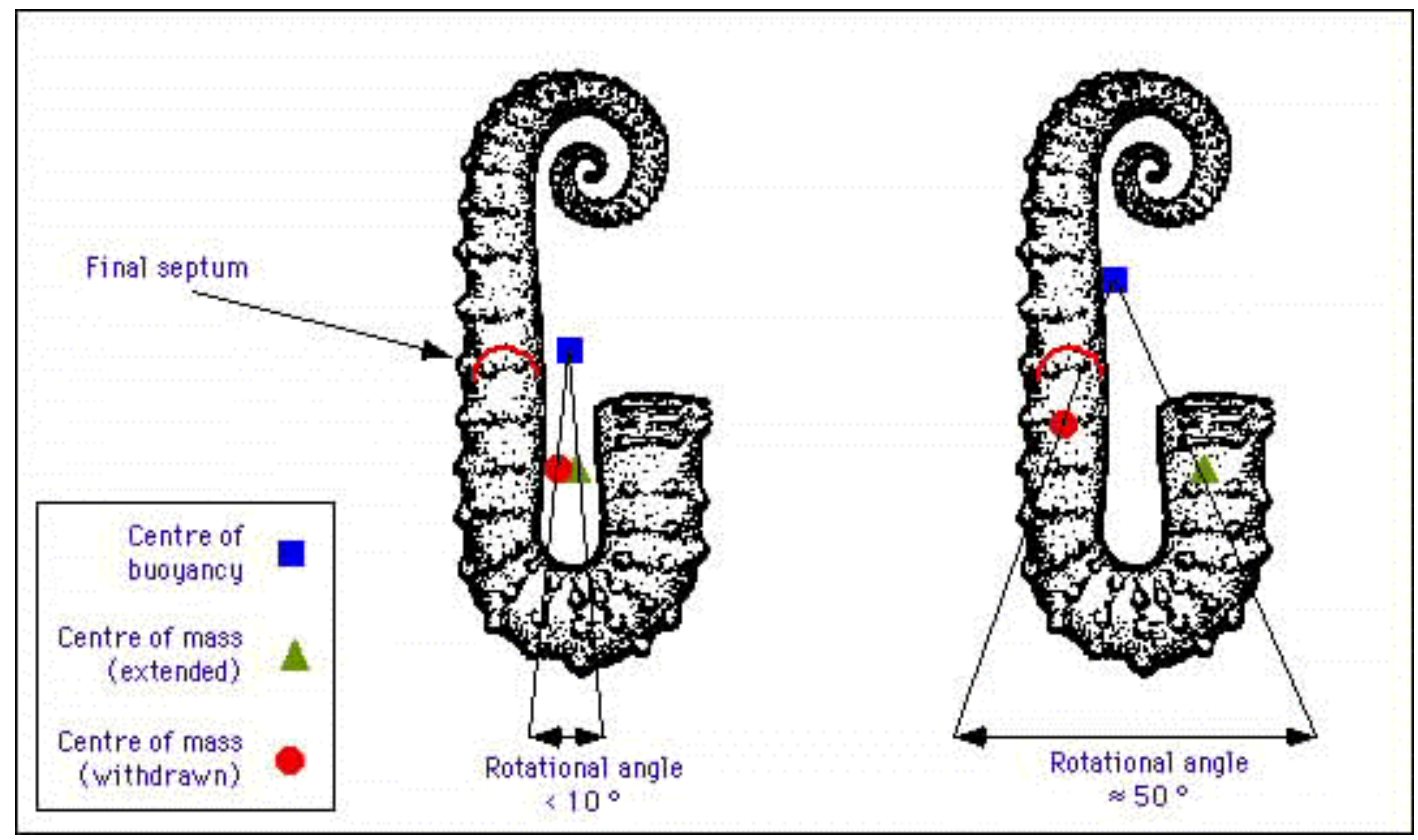


Figure 3. Centres of buoyancy (blue squares) and mass (green triangle and red circle) for Hamites maximus deduced using Trueman's model with the body chamber entirely filled (left); and the model presented here, with the body chamber only partially filled (right). The green triangle indicates the position of the centre of mass when the head and arms are extended; the red circles when withdrawn.

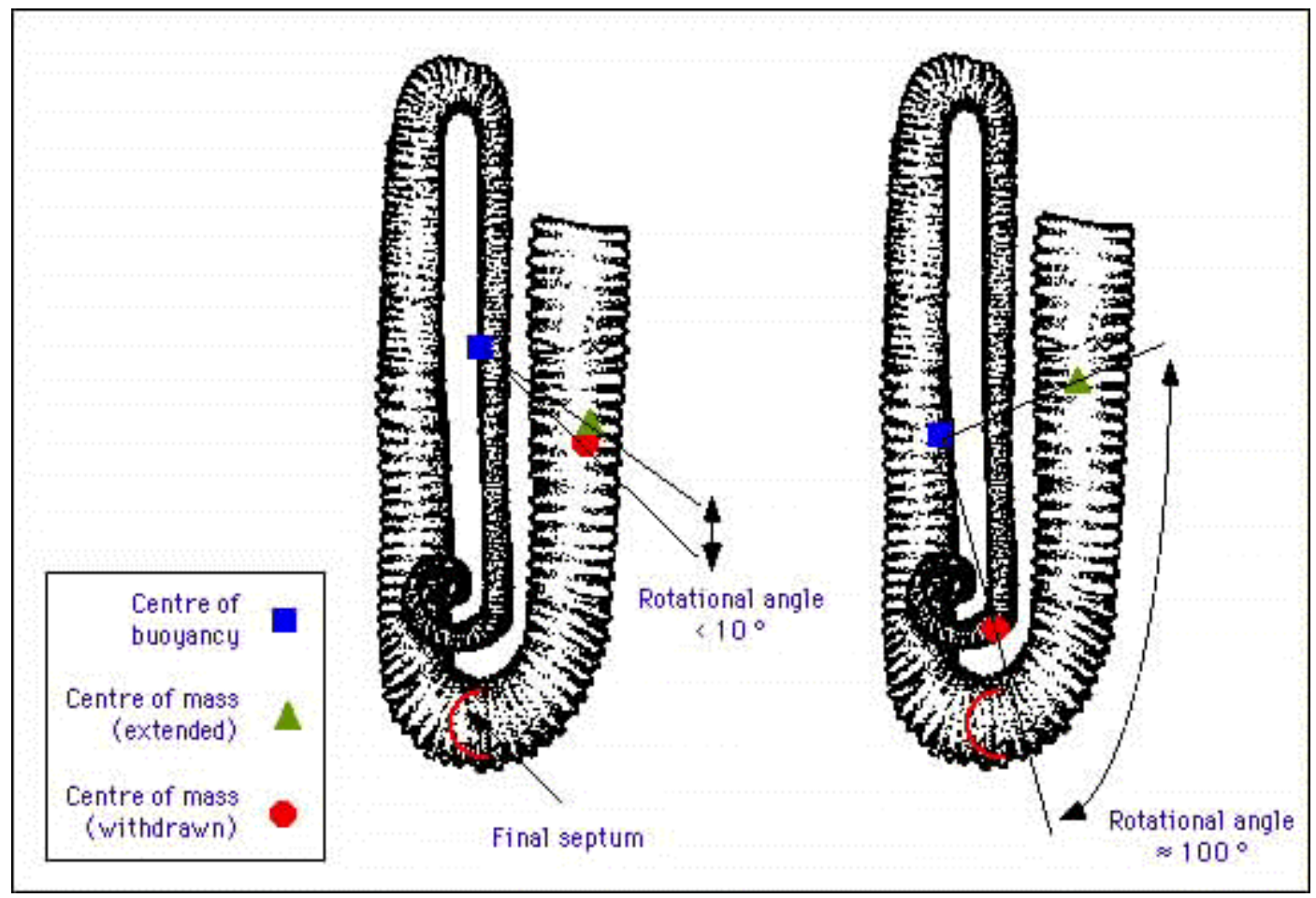


Animation 1. QuickTime (trademark) movie based on an the usual view of ammonite anatomy, where the body chamber is completely filled, as proposed by Trueman (1941).

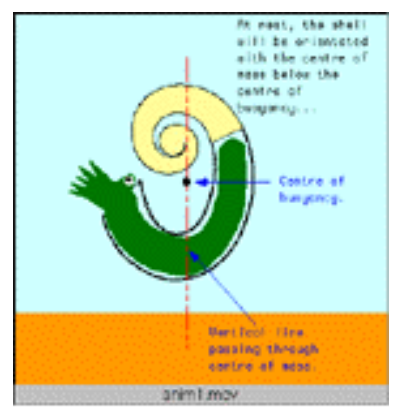

Animation 1.

\title{
Functional Morphology of Heteromorph Ammonites
}

\author{
Neale Monks \& Jeremy Young
}

Department of Palaeontology,

Hatural History Museum, London.

Movie 1: This is based on the work of Trueman (1941), who proposed that the entire living chamber was filled by the animal. Withdrawal of the head and arms into the shell has little affect on orientation. If their anatomy was like this, ammonites would be very stable but in a single orientation only. 
Animation 2. QuickTime (trademark) movie based on the proposal by Kakabadzé and Sharikadzé (1993) that ammonites may have changed orientation by shifting cameral fluids within the shell.

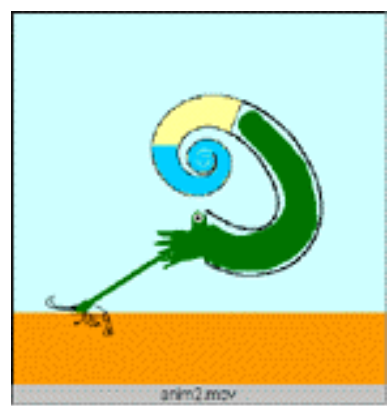

Animation 2.

\title{
Functional Morphology of Heteromorph Ammonites
}

\author{
Neale Monks \& Jeremy Young
}

Department of Palaeontology,

Natural History Museum, London.

Movie 2: This is based on a recent paper by Kakabadzé and Sharikadzé (1993), who suggested that movement of cameral fluid within the shell could be used to change the shell's orientation. This would allow the shell more than one stable orientation. 
Animation 3. QuickTime (trademark) movie demonstrating the proposal made here that withdrawal or extension of the soft body parts within the living chamber could produce changes in the orientation of the shell.

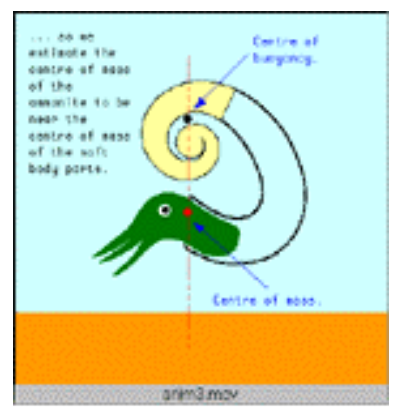

Animation 3.

\title{
Functional Morphology of Heteromorph Ammonites
}

\author{
Neale Monks \& Jeremy Young \\ Department of Palaeontology, \\ Hatural History Museum, \\ London.
}

Movie 3: We propose that the ammonite body may have been small and mobile, and that movement of the body within the shell would be sufficient to change the orientation relative to the sea floor. 
Table 1. Approximate rotational angles of three heteromorph ammonite designs. The dimensions of the original shells of three different designs are compared with the estimated rotational angles based on our model. All lengths to the nearest $5 \mathrm{~mm}$, angles to the nearest $5^{\circ}$.

$\begin{array}{llll}\text { Shell Type } & \text { Aspinocone } & \text { Ancylcone } & \text { Hamiticone } \\ \text { Genus } & \text { Tropaeum } & \text { Ancycloceras } & \text { Hamites } \\ \text { Whorl height } & 60 \mathrm{~cm} & 40 \mathrm{~cm} & 30 \mathrm{~cm} \\ \text { Whorl width } & 50 \mathrm{~mm} & 20 \mathrm{~mm} & 10 \mathrm{~mm} \\ \text { Rotational angle } & 40^{\circ} & 50^{\circ} & 100^{\circ}\end{array}$

